\title{
Cellulolytic Enzymes in Culture Filtrates of Aspergillus clavatus
}

\author{
By P. O. OLUTIOLA \\ Department of Microbiology, University of Ife, Nigeria
}

(Received 20 April 1977)

Aspergillus clavatus grew in synthetic liquid media with soluble or insoluble cellulose as sole carbon source, releasing cellulolytic enzymes into the media. These enzymes were separated by molecular exclusion and ion exchange chromatography into four components. When assayed for hydrolysis of insoluble cellulose, the combined fractions released more glucose than when each component was tested alone.

\section{INTRODUCTION}

Aspergillus clavatus Desm. is a phytopathogenic fungus associated with internal mouldiness of cocoa beans in Nigeria (Broadbent, 1968; Oyeniran, 1970). Many plant pathogens produce a complex of extracellular cellulases which hydrolyse the cellulosic components of host cell wall. Such a complex of cellulases has been isolated from some species of Aspergillus and other fungi (Olutiola \& Cole, 1976; Youatt, 1958; Coutts \& Smith, 1976; Almin \& Eriksson, 1968).

Production of fungal cellulases is greatly influenced by cultural conditions. For example, maximum production of cellulase from Aspergillus tamarii was at $\mathrm{pH} 4.5$ (Olutiola \& Cole, 1976) but that of Aspergillus luchuensis was at pH 6.5 to 7.0 (Reese \& Levinson, 1952).

This paper examines the ability of $A$. clavatus to produce cellulolytic enzymes in vitro. The composition and activity of these enzymes are also examined.

\section{METHODS}

Organism and culture conditions. The isolate (NSPRIIO9) of Aspergillus clavatus used was from the culture collection of the Nigerian Stored Products Research Institute. It was isolated from mouldy cocoa beans. The organism was routinely grown and maintained on $\mathrm{I} \%(\mathrm{w} / \mathrm{v})$ malt yeast extract agar. Each flask was inoculated with $\mathrm{I} \mathrm{ml} \mathrm{of} \mathrm{an} \mathrm{aqueous} \mathrm{spore} \mathrm{suspension} \mathrm{containing} \mathrm{approximately} 4 \times 10^{6}$ spores $\mathrm{ml}^{-1}$. Cultures were grown in a defined liquid medium (Olutiola, 1976) containing $\mathrm{r} \%(\mathrm{w} / \mathrm{v})$ carboxymethylcellulose (CMcellulose). Other carbon sources, cellulose film (Lansil Ltd., Lancaster), cellobiose (BDH), cellulose powder (Difco), Whatman no. I filter paper and viscose cellulose (Gallenkamp) were each used separately to give $\mathrm{I} \%(\mathrm{w} / \mathrm{v})$ carbon source. The CM-cellulose and cellobiose were dissolved by mechanical agitation. Discs ( $2 \mathrm{~cm}$ diam.) of Whatman no. 1 filter paper were used. Cellulose powder was ball-milled for $72 \mathrm{~h}$. The cellulose film and viscose cellulose were each boiled to remove plasticizers. Each $150 \mathrm{ml}$ Erlenmeyer flask contained $50 \mathrm{ml}$ of medium and was incubated without shaking at $30{ }^{\circ} \mathrm{C}$. On each carbon source, growth was judged to occur when there was a noticeable increase in the fungal mats produced.

Preparation of enzyme solution. After 9 days of incubation, unless otherwise stated, the contents of each flask were filtered through a glass-fibre filter (Whatman GF/A). The reducing sugars and protein content of the filtrates were measured using the methods of Miller (1959) and Lowry et al. (195I), respectively.

One litre of the filtrate was precipitated with $\left(\mathrm{NH}_{4}\right)_{2} \mathrm{SO}_{4}$ (analytical grade, $\left.\mathrm{BDH}\right)$ at 40 to $95 \%(\mathrm{w} / \mathrm{v})$ saturation (Wood, 1968; Whitaker, Hanson \& Datta, 1963; Dixon \& Webb, 197I). The precipitate was redissolved in phosphate buffer, pH 6.5 (containing $6.7 \mathrm{~mm}-\mathrm{NaH}_{2} \mathrm{PO}_{4}, 100 \mathrm{~mm}-\mathrm{NaCl}$ and $3.3 \mathrm{mM}_{-} \mathrm{Na}_{2} \mathrm{HPO}_{4}$ ) to give a 20 -fold concentration of the original culture filtrate. The filtrate was then dialysed for $24 \mathrm{~h}$ at $4{ }^{\circ} \mathrm{C}$ using acetylated cellophane tubing prepared from Visking dialysis tube (Gallenkamp) as previously described (Whitaker et al., 1963). The filtrate was sterilized by membrane filtration (pore size $0.45 \mu \mathrm{m}$, Oxoid) before 
separation and assay procedures. The dialysed filtrate, when diluted 20-fold, possessed all the activity of the original crude culture filtrate towards cellulosic substrates.

Enzyme separation. A column $(2.5 \times 70 \mathrm{~cm})$ of Sephadex G-75, surrounded by a water jacket maintained at $20^{\circ} \mathrm{C}$, was prepared and calibrated as previously described (Olutiola, 1976). Ten $\mathrm{ml}$ of the enzyme concentrate were applied to the column and eluted with phosphate buffer, $\mathrm{pH} 6: 5$, containing $(\mathrm{mm}): \mathrm{NaN}_{3}, 5$; $\mathrm{NaCl}, 100 ; \mathrm{NaH}_{2} \mathrm{PO}_{4}, 6 \cdot 7$; and $\mathrm{Na}_{2} \mathrm{HPO}_{4}, 3 \cdot 3$. The protein content of the eluted fractions was recorded by continuous measurement of the extinction at $280 \mathrm{~nm}$ and fractions $(4.5 \mathrm{ml}$ per tube) were collected in an LKB automated fraction collector (7000 A Ultra Rac).

Fractions ( 16 to 23) which showed appreciable cellulase activity after gel filtration, were combined and low molecular weight substances were removed by mixing with dry, coarse Sephadex G-25 for 10 min (Flodin, Gelotte \& Porath, 1960). This process also helped to concentrate the enzyme fraction. The enzyme concentrate was made up to $15 \mathrm{ml}$ in succinate buffer, pH 5.2 (containing $5 \mathrm{~mm}-\mathrm{NaN}_{3}, 0.2 \mathrm{M}-\left(\mathrm{CH}_{2} \mathrm{COOH}\right)_{2}$ and $0.2 \mathrm{M}-\mathrm{NaOH})$, and applied to a column $(2.5 \times 40 \mathrm{~cm})$ of $\mathrm{CM}$-Sephadex $\mathrm{C}-50$ surrounded by a water jacket at $20^{\circ} \mathrm{C}$ and equilibrated with succinate buffer $(\mathrm{pH} 5 \cdot 2)$. Fractions $(3.5 \mathrm{ml}$ per tube) were collected and measured as described above.

Assay methods. $\mathrm{C}_{x}$ cellulase and cellobiase activities were obtained by measuring the reducing sugars released in reaction mixtures. Each reaction mixture contained $0.4 \mathrm{ml}$ of the enzyme preparation and I $\mathrm{ml}$ of CM-cellulose $\left(5 \mathrm{mg} \mathrm{ml}^{-1}\right)$ or cellobiose $\left(0.7 \mathrm{mg} \mathrm{ml}^{-1}\right)$ in $0.1 \mathrm{M}$-citrate/phosphate buffer $\left(\mathrm{pH}_{4} .5\right)$, and was incubated at $30^{\circ} \mathrm{C}$ for $\mathrm{I} h$. The reducing sugars released were measured by the method of Miller (I959). The unit of activity (u.) is defined as the amount of enzyme in I ml of reaction mixture that liberates reducing sugar equivalent to Io $\mu \mathrm{g}$ glucose.

$\mathrm{C}_{x}$ cellulase activity was also assayed viscometrically in an Ostwald viscometer (British Standard Units, size C, Gallenkamp) containing $4 \mathrm{ml}$ enzyme solution and $6 \mathrm{ml} \mathrm{CM}$-cellulose ( $10 \mathrm{mg} \mathrm{ml}^{-1}$ ) in O.I M-citrate/ phosphate buffer $\left(\mathrm{pH}_{4.5)}\right.$ at $30^{\circ} \mathrm{C}$ for $30 \mathrm{~min}$. The activity of the enzyme was expressed as the percentage loss in viscosity of the CM-cellulose (Norkrans \& Hammarström, 1963).

The activity of the protein fractions, singly and in combination, towards insoluble cellulose was measured by incubating $5 \mathrm{mg}$ cellulose powder, I $\mathrm{ml} \mathrm{O} \cdot \mathrm{I}$ M-citrate/phosphate buffer $(\mathrm{pH} 4.5), 0.4 \mathrm{ml}$ enzyme solution and $5 \mathrm{~mm}$-sodium azide (BDH) for $72 \mathrm{~h}$ at $30^{\circ} \mathrm{C}$. The unhydrolysed cellulose left after incubation was separated from the reaction mixture by centrifuging at $10000 \mathrm{~g}$ for $10 \mathrm{~min}$ at $4{ }^{\circ} \mathrm{C}$. The supernatant was carefully removed with a pasteur pipette and analysed for glucose by a modified technique of De Verdier \& Hjelm (I962) in which the galactose oxidase was replaced by glucose oxidase. The unit of activity (u.) is defined as the amount of enzyme in I $\mathrm{ml}$ of reaction mixture that liberates $10 \mu \mathrm{g}$ glucose.

\section{RESULTS AND DISCUSSION}

\section{Growth on cellulosic substrates and enzymic activity of culture filtrates}

Aspergillus clavatus was able to grow on both CM-cellulose and cellobiose and insoluble forms of cellulose (Whatman no. I filter paper, viscose cellulose, cellulose film and cellulose powder) indicating production of $C_{1}$ cellulase (Selby \& Maitland, 1967; Whitney, Chapman \& Heale, 1969). Hydrolysis of CM-cellulose was indicated by a noticeable decrease in the viscosity of the CM-cellulose medium and by an increase in cell mass which corresponded to the protein concentration and reducing sugars liberated into the medium.

Culture filtrates liberated reducing sugars from CM-cellulose and cellobiose over a wide range of $\mathrm{pH}$ values with an optimum at $\mathrm{pH} 4.5$ (Table I). Ability of the filtrate to hydrolyse $\mathrm{CM}$-cellulose and cellobiose is indicative of $\mathrm{C}_{x}$ cellulase and cellobiase activity.

\section{Fractionation of cellulase complex}

Fractionation of the enzyme concentrate ( $10 \mathrm{ml}$ ) on Sephadex G-75 produced a single peak designated A (Fig. I). The molecular weight of this component estimated from the elution volume was approximately I05900. The component possessed $\mathrm{C}_{x}$ cellulase and cellobiase activity, indicating that both types of enzymes were eluted together. Previous workers (Selby \& Maitland, I967; Wood, 1968; Olutiola \& Ayres, 1973) were also unable to separate $\mathrm{C}_{x}$ cellulases from cellobiases by passage through Sephadex G-75.

Fractionation of component A on Sephadex C-50 gave four new absorption peaks designated $\mathrm{Aa}, \mathrm{Ab}, \mathrm{Ac}$ and Ad respectively (Fig. 2). When these components were mixed 
Table I. Effect of $p H$ on the enzymic activity of culture filtrates of Aspergillus clavatus incubated with CM-cellulose $(0.5 \%, w / v)$ or cellobiose $\left(0.7 \mathrm{mg} \mathrm{ml}^{-1}\right)$ for $90 \mathrm{~min}$

Each value represents enzyme activity $\left(u . \mathrm{ml}^{-1}\right)$ and is the mean of three replicates.

\begin{tabular}{lrrrrrrrr} 
& \multicolumn{8}{c}{$\mathrm{pH}$} \\
Substrate & 2.5 & 3.5 & 4.5 & 5.5 & 6.5 & 7.5 & 8.5 & 9.5 \\
CM-cellulose & $\mathrm{I} \cdot 9$ & 5.8 & $8 . \mathrm{I}$ & $6 . \mathrm{I}$ & 4.9 & $\mathrm{I} \cdot 8$ & $\mathrm{I} \cdot 2$ & 0.9 \\
Cellobiose & 2.7 & 4.9 & 17.7 & 14.7 & 7.6 & 3.2 & 2.4 & 1.5
\end{tabular}

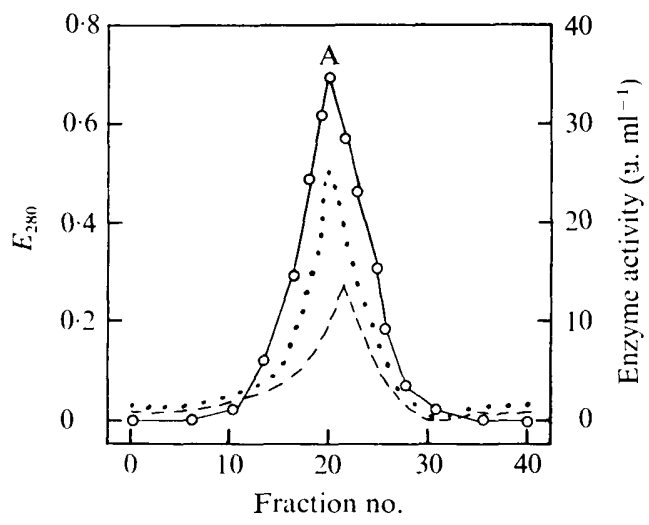

Fig. I

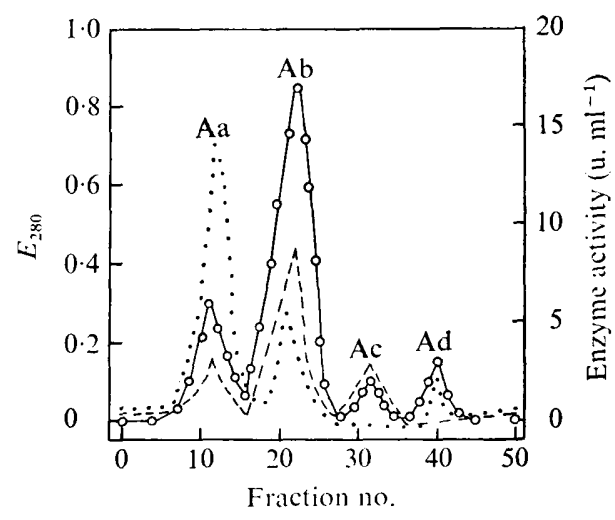

Fig. 2

Fig. I. Separation by gel filtration of proteins in concentrated culture filtrates ( 40 to $95 \%$ saturated $\left(\mathrm{NH}_{4}\right)_{2} \mathrm{SO}_{4}$ fraction redissolved to give a 20 -fold concentration) of $A$. clavatus, and enzymic activity of the fractions towards $\mathrm{CM}$-cellulose and cellobiose. $\mathrm{O}-\mathrm{O}$, Protein $\left(\mathrm{E}_{280}\right) ;---, \mathrm{C}_{x}$ cellulase activity; ..., cellobiase activity.

Fig. 2. Separation by ion exchange chromatography of proteins (fractions 16 to 23) previously separated from culture filtrates of $A$. clavatus by gel filtration (Fig. I), and enzymic activity of the fractions towards $\mathrm{CM}$-cellulose and cellobiose. $\bigcirc-O$, Protein $\left(E_{280}\right) ;---, \mathrm{C}_{x}$ cellulase activity; ..., cellobiase activity.

and rechromatographed on Sephadex G-75 column, they all produced a single absorption peak, and were collected in exactly the same fraction tubes as component $A$, indicating that these components (Aa, $\mathrm{Ab}, \mathrm{Ac}$ and $\mathrm{Ad}$ ) are of similar molecular weight.

The enzymic activity of each component was examined (Fig. 2). Components $\mathrm{Aa}$ and $\mathrm{Ab}$ were able to hydrolyse CM-cellulose and cellobiose and thus still possess $\mathrm{C}_{x}$ cellulase and cellobiase activities. Component Ac hydrolysed CM-cellulose and failed to act on cellobiose. This component therefore appears to be a cellobiase-free form of $\mathrm{C}_{x}$ cellulase. Component Ad degraded cellobiose but not CM-cellulose, indicating a separated form of cellobiase, completely free from $\mathrm{C}_{x}$ cellulase activity. Thus, there were differences in substrate specificity between the components separated on the CM-50 column. Other workers (Selby \& Maitland, 1967; Streamer, Eriksson \& Petterson, 1975) have also demonstrated differences in the type of cellulosic substrates degraded by various components of cellulolytic enzyme systems.

The activity of the components towards insoluble cellulose powder was also examined. Components were examined singly and in various combinations such that the original cellulase complex was reconstituted in a stepwise manner (Table 2). Release of glucose from the cellulose was indicative of enzyme activity. Each component hydrolysed insoluble cellulose to release glucose as an end-product. When the components were combined, more glucose was released from insoluble cellulose than when each component was tested alone. Whenever the component under test contained the component Ac, there was a synergistic increase in the hydrolysis of cellulose, since under such conditions more glucose was released than could 
Table 2. Enzymic activity (towards insoluble cellulose powder) of cellulase components separated from culture filtrates of Aspergillus clavatus

Reaction mixtures were incubated for $72 \mathrm{~h}$.

\begin{tabular}{|c|c|c|}
\hline Means of separation & Components & $\begin{array}{l}\text { Enzyme ac } \\
\quad \text { (u. } \mathrm{ml}^{-}\end{array}$ \\
\hline None & Culture filtrate & $3 \cdot 8$ \\
\hline None & $\begin{array}{l}40 \text { to } 95 \% \text { saturated }\left(\mathrm{NH}_{4}\right)_{2} \mathrm{SO}_{4} \\
\text { concentrate (2O-fold) }\end{array}$ & 14.9 \\
\hline None & $\begin{array}{l}40 \text { to } 95 \% \text { saturated }\left(\mathrm{NH}_{4}\right)_{2} \mathrm{SO}_{4} \\
\text { concentrate }(20 \text {-fold }) \text {, diluted } \times 20\end{array}$ & 4.5 \\
\hline Sephadex G-75 & A & $13 \cdot 6$ \\
\hline Sephadex C-50 of component $\mathbf{A}$ & $\begin{array}{c}\mathrm{Aa} \\
\mathrm{Ab} \\
\mathrm{Ac} \\
\mathrm{Ad} \\
\mathrm{Aa}+\mathrm{Ab} \\
\mathrm{Aa}+\mathrm{Ac} \\
\mathrm{Aa}+\mathrm{Ad} \\
\mathrm{Ab}+\mathrm{Ac} \\
\mathrm{Ab}+\mathrm{Ad} \\
\mathrm{Ac}+\mathrm{Ad} \\
\mathrm{Aa}+\mathrm{Ab}+\mathrm{Ac}+\mathrm{Ad}\end{array}$ & $\begin{array}{r}3 \cdot 5 \\
2 \cdot 0 \\
2 \cdot 8 \\
3 \cdot 2 \\
3 \cdot 9 \\
9 \cdot 6 \\
4 \cdot 3 \\
7 \cdot 4 \\
3 \cdot 5 \\
8 \cdot 4 \\
13 \cdot 0\end{array}$ \\
\hline
\end{tabular}

be predicted from an examination of the components alone. Thus, component Ac has the character of a $C_{1}$ cellulase (Selby \& Maitland, 1967; Eriksson \& Rzedowski, I969; Shikata \& Nisizawa, 1975). It resembles the $\mathrm{C}_{1}$ component of $\mathrm{Li}$, Flora \& King (1965) and Wood (I968), but differs from the $\mathrm{C}_{1}$ component of Selby \& Maitland (1967), Olutiola \& Ayres (1973) and Olutiola (1976), because of its ability to hydrolyse soluble cellulose. Such synergism between separated components of cellulases has been reported for a number of phytopathogenic fungi (Umeruzike, 1970; Olutiola \& Cole, 1976; Olutiola 1976; Streamer et al., 1975).

The cellulolytic enzyme system of $A$. clavatus consists of components which exhibit substrate specificity. Production of a complex of cellulase enzymes is believed to be of advantage to a phytopathogen, since it can then attack celluloses at different stages of degradation, from the highly complex and insoluble forms to the simpler and soluble ones which can be absorbed and utilized by the organism (Whitney et al., I969; Olutiola, 1972; Shikata \& Nisizawa, 1975).

\section{REFERENCES}

Almin, K. E. \& Eriksson, K. E. (I968). Influence of carboxymethyl cellulose properties on the determination of cellulase activity in absolute units. Archives of Biochemistry and Biophysics 124, I 29-I 34.

BROADBENT, J. A. (I968). The importance of different moulds in causing internal mouldiness of Nigerian cocoa. Reprint of the Nigerian Stored Products Research Institute. Technical Report no. 5, pp. 53-57.

Coutrs, A. D. \& Sмrтh, R. E. (1976). Factors influencing the production of cellulases by Sporotrichum thermophile. Applied Environmental Microbiology 3r, 819-825.

De Verdier, C. H. \& HJelm, M. (I962). A galactose oxidase method for determination of galactose in blood plasma. Clinica chimica acta 7, 724744.

DiXON, M. \& WebB, E. C. (197I). Enzymes. Great Britain: William Clowes \& Sons.
Eriksson, K. E. \& Rzedowski, W. (1969). Extracellular enzyme system utilized by the fungus Chrysosporium lignorum for the breakdown of cellulose. I. Studies on the enzyme production. Archives of Biochemistry and Biophysics 129, 683-688.

Flodin, P., Gelotte, B. \& Porath, J. (1960). A method for concentrating solutes of high molecular weight. Nature, London 188, 493-494.

LI, L. H., Flora, K. M. \& KING, K. W. (I965), Individual roles of cellulase components derived from Trichoderma viride. Archives of Biochemistry and Biophysics III, 439-447.

Lowry, O. H., Rosebrough, N. J., Farr, A. L. \& RANDAll, R. J. (195I). Protein measurement with the Folin phenol reagent. Journal of Biological Chemistry 193, 265-275.

Miller, G. L. (I959). Use of dinitrosalicyclic acid reagent for determination of reducing sugar. Analytical Chemistry 31, 426-428. 
Norkrans, B. \& Hammarström, A. (1963). Studies on growth of Rhizina undulata Fr. and its production of cellulose- and pectin-degrading enzymes. Physiologia plantarum 16, I-10.

Olutiola, P. O. (1972). Aspects of the carbohydrate physiology of Rhynchosporium secalis. Ph.D. thesis, University of Lancaster.

Olutiola, P. O. (1976). Cellulolytic enzymes in culture filtrates of Rhizoctonia lamellifera. Journal of General Microbiology 97, 25I-256.

Olutiola, P. O. \& Ayres, P. G. (1973). A cellulase complex in culture filtrates of Rhynchosporium secalis. Transactions of the British Mycological Society 60, 273-282.

Olutiola, P. O. \& Cole, O. O. (1976). Production of a cellulase complex in culture filtrates of Aspergillus tamarii associated with mouldy cocoa beans in Nigeria. Physiologia plantarum 37, 3133 I6.

OYENIRAN, J. O. (1970). Internal mouldiness of commercial cocoa in Ibadan, Western State, Nigeria. Reprint of the Nigerian Stored Products Research Institute. Technical Report no. 2, pp. 5I-53.

ReEse, E. T. \& Levinson, H. S. (I952). A comparative study of breakdown of cellulose by microorganisms. Physiologia plantarum 5, 345-366.

Selby, K. \& Martland, C. C. (I967). The cellulase of Trichoderma viride. Separation of the components involved in the solubilization of cotton. Biochemical Journal 104, 7I6-724.

Shikata, S. \& Nisizawa, K. (1975). Purification and properties of an exo-cellulase component of novel type from Trichoderma viride. Journal of Biochemistry 78, 499-5I 2.

Streamer, M., Eriksson, K. E. \& Petterson, B. (1975). Extracellular enzyme system utilized by the fungus Sporotrichum pulverulentum (Chrysosporium lignorum) for the breakdown of cellulose. Functional characterization of five endo- $I, 4-\beta-$ glucanases and one exo-I, 4- $\beta$-glucanase. European Journal of Biochemistry 59, 607-613.

UMeruziKe, G. M. (I970). Cellulase and $\beta$-glucosidase components in culture filtrates of Botryodiplodia theobromae Pat. Journal of Experimental Botany 21, 639-650.

Whitaker, D. R., Hanson, K. R. \& DatTa, P. K. (1963). Improved procedures for preparation and characterization of Myrothecium cellulase. 2. Purification procedures. Canadian Journal of Biochemistry and Physiology 4I, 67I-696.

Whitney, P., Chapman, J. M. \& Heale, J. B. (1969). Carboxymethylcellulase production by Verticillium albo-atrum. Journal of General Microbiology 56, 21 5-225.

Wood, T. M. (1968). Cellulolytic enzyme system of Trichoderma koningii. Separation of components attacking native cotton. Biochemical Journal rog, 217-227.

YouatT, G. (1958). Fungal cellulases. IX. Growth of Stachybotris atra on cellulose and production of a $\beta$-glucosidase hydrolysing cellobiose. Australian Journal of Biological Science 11, 209-217. 